\title{
CAMBA, a New Synthesized and Promising Protector against STZ-Induced Diabetic Complications in Rats
}

\author{
Mohammed A Hussein ${ }^{1 *}$ and Naglaa A Gobba ${ }^{2}$ \\ ${ }^{1}$ Biochemistry Department, Faculty of Pharmacy, October 6 University, October 6 city, Egypt \\ ${ }^{2}$ Pharmacology Department, Faculty of Pharmacy, Misr University for Science \& Technology (MUST), October 6 city, Egypt
}

\begin{abstract}
CAPE, one of the most active compounds in propolis, is the perfect illustration of a natural compound exhibiting diverse biological activities. However, rapid decomposition by esterase leads to its low bioavailability in vivo. The aim of the present study is to synthesis and investigates the antioxidant and protective activities of novel derivative of caffeic acid, CAMBA against STZ-induced diabetic complications in diabetic rats. Since amide is more resistant to esterase enzyme. CAMBA was synthesized by reacting the amino group of methyl anthranilate with caffeic acid in the presence of $\mathrm{PCl}_{3}$. Diabetic rats was induced by injection of STZ ( $55 \mathrm{mg} / \mathrm{kg}$, i.p.) and diabetes was confirmed $48 \mathrm{~h}$ after induction, and then allowed for 7 days to stabilize blood glucose level. CAMBA ( 25 and $50 \mathrm{mg} / \mathrm{kg} \mathrm{b.w}$ daily for 28 days) treated diabetic rats significantly reduced elevated blood glucose, TC, TG, atherogenic index, LDL-C, vLDL-C, hepatic, renal and cardiac TBARs and HP. The treatment also resulted in improved the insulin and insulin resistance and significantly increased serum HDL-C and GSH, SOD, CAT and GPx in the liver, kidney and heart of diabetic rats. The results clearly suggest that CAMBA treated group may effectively normalize the impaired antioxidant status in streptozotocin induced diabetes than the glibenclamide-treated groups. CAMBA exerted rapid protective effects against lipid peroxidation by scavenging of free radicals by reducing the risk of diabetic complications. Taken together, CAMBA has potential as an antioxidant agent for diabetes and deserves clinical trial in the near future as an adjuvant therapy in diabetic patients.
\end{abstract}

Keywords: CAMBA; Antioxidant; STZ; Oxidative stress biomarkers and diabetic complications

Abbreviations: CAPE: Caffeic Acid Phenylethyl Ester; CAMBA: Caffeic Acid Methyl Benzoate Amide; TC: Total-Cholesterol; LDL-c: Low Density Lipoprotein-Cholesterol; vLDL-c: Very Low Density Lipoprotein-Cholesterol; HDL-c: High Density LipoproteinCholesterol, TBARs: Thiobarbituric Acid Reactive Substances, HP: Hydroperoxides, GSH: Reduced Glutathione, SOD: Superoxide Dismutase, CAT: Catalase, GPx: Glutathione Peroxidase, GST: Glutathione-S-Transferase; STZ: Streptozotocin

\section{Introduction}

Diabetes mellitus (DM) represents a range of metabolic disorders characterized by hyperglycemia resulting from insulin deficiency or insulin resistance or both [1,2]. Complications caused by hyperglycaemia involve damage to the small vessels such as in neuropathy, nephropathy, and retinopathy, and large blood vessels as in cardiovascular diseases [3-5]. STZ is potential to act as an intracellular nitric oxide (NO) donor and generates reactive oxygen species (ROS) $[6,7]$. The synergistic action of both NO and ROS may also contribute to DNA fragmentation and other deleterious changes caused by STZ [8]. Many natural polyphenolic compounds are demonstrated to have anti-inflammatory, antioxidant, anticarcinogenic, antithrombotic, and cardiovascular protective effects [9-11]. Caffeic acid, the main representative of the hydroxycinnamic and phenolic acids, is found in many plants as simple derivatives such as glycosides, amides, esters and sugar esters. Caffeic acid phenylethyl ester (CAPE) (Figure 1), one of the most active compounds in propolis, is the perfect illustration of a natural compound exhibiting diverse biological activities. Numerous studies have shown that CAPE has antioxidant, anti-inflammatory and hepatoprotective activities [12-14]. However, the rapid metabolism of CAPE by esterase leads to its low bioavailability.

The antioxidant activities of CAMBA are based on structural factors as well as the medium used to assay these activities [15]. Hussein [15] showed that free radical scavenging activity was dependent on the presence of catechol, hydroxyl groups and the $\mathrm{H}$ donating groups.
Also, the hydrophobicity of CAMBA was also an important factor in determining their activity [15]. In addition to these known structural features, it was further demonstrated that phenolic acids bearing a carbonyl group separated from the aromatic ring were more active [15]

As an extension of our studies on the synthesis of some new biologically active heterocyclic compounds $[15,16]$, now we wish to report the synthesis caffeic acid methyl benzoate amide (CAMBA), a caffeic acid amide derivative and structurally similar to CAPE. Since amide is more resistant to esterase, it is foreseeable that CAMBA is more stable than CAPE in vivo. The present investigation was undertaken to assess the effect of CAMBA on tissue lipid peroxides and enzymatic antioxidant in STZ-induced diabetic rats, which may pave the way for possible therapeutic application.

\section{Experimental}

\section{Chemistry}

Melting points were determined on Gallenkamp melting point apparatus and are uncorrected. The infrared (IR) spectra were recorded on Shimadzu MR470 infrared spectrophotometer using the $\mathrm{KBr}$ pellets. ${ }^{1} \mathrm{H}$ - and ${ }^{13} \mathrm{C}$ NMR spectra were recorded in DMSO- $\mathrm{d}_{6}$ and $\mathrm{CD}_{3} \mathrm{OD}$, respectively, on a Varian EM $360\left({ }^{1} \mathrm{H} \mathrm{NMR}\right.$ at $\left.240 \mathrm{MHz}\right)$ and $\left({ }^{13} \mathrm{C} \mathrm{NMR}\right.$ at $\left.75 \mathrm{MHz}\right)$. The chemical shifts are reported in part per million $(\delta \mathrm{ppm})$ downfield from internal tetramethylsilane (TMS).

*Corresponding author: Mohammed A Hussein, Ph.D., Department of Biochemistry, Faculty of Pharmacy, October $6^{\text {th }}$ University, October $6^{\text {th }}$ City, Egypt, Tel: $+2(0122)$ 4832580; Fax: +2 (02) 38353270; E-mail: abdallamohammed_304@yahoo.com

Received September 17, 2013; Accepted November 27, 2013; Published November 29, 2013

Citation: Hussein MA, Gobba NA (2013) CAMBA, a New Synthesized and Promising Protector against STZ-Induced Diabetic Complications in Rats. Med chem 3: 286-293. doi:10.4172/2161-0444.1000153

Copyright: (c) 2013 Hussein MA, et al. This is an open-access article distributed under the terms of the Creative Commons Attribution License, which permits unrestricted use, distribution, and reproduction in any medium, provided the original author and source are credited. 


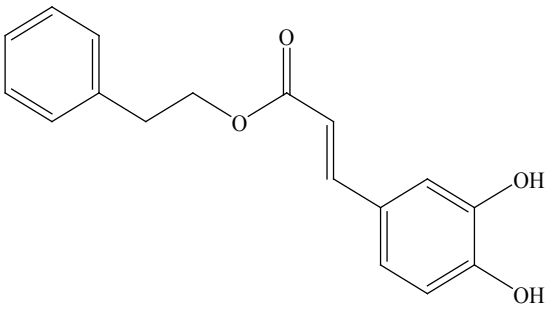

Figure 1: Caffeic acid phenylethyl ester (CAPE)

Mass spectra were run using HP Model MS-5988. Microanalytical data $(\mathrm{C}, \mathrm{H}, \mathrm{N})$ were determined at the Microanalytical Center, Cairo University, Egypt.

Synthesis of caffeic acid methyl benzoate amide (CAMBA): Caffeic acid methyl benzoate amide (CAMBA) was prepared as the method adapted by Hussein [15]. To a solution of caffeic acid $(0.01$ $\mathrm{mol})$ and methylanthranilate $(2.31 \mathrm{~g}, 0.01 \mathrm{~mol})$ in xylene $(50 \mathrm{ml})$, phosphorus trichloride $(3 \mathrm{ml})$ was added. The reaction mixture was heated under reflux for 3-4 h. The crude product was recrystallized from ethanol to give CAMBA.

\section{Animals}

Male albino rats weighing around $230 \pm 10 \mathrm{~g}$ were purchased from Faculty of Veterinary Medicine, Cairo University. The reason that potentiates us to use rats for testing is because they are simply easy to find, their blood and organs; liver, kidney and heart are enough to make all biochemical analysis. All the rats were given a period of acclimatization for 15 days before starting the experiment. Animals were provided with standard diet and water ad libtum and were kept on a $12 \mathrm{~h}$ ligth/12 $\mathrm{h}$ dark cycle, in a room with the temperature regulated to $21-25^{\circ} \mathrm{C}$ and humidity at roughly $56 \%$. All protocols were performed in accordance with the Institutional Animal Ethical Committee (IAEC) as per the directions of Faculty of Pharmacy October 6 University, Egypt.

\section{Acute toxicity studies}

Acute oral toxicity of CAMBA study was performed as the method adapted by Hussein [15]. Administration of stepwise dose of CAMBA (400, 800 and $1000 \mathrm{mg} / \mathrm{kg}$ b.wt), animals were observed individually during the first 30 minutes and periodically during the first 24 hours, with special attention given during the first 4 hours and daily thereafter, for total of 21 days. The parameters observed were growing, hyperactivity, sedation, loss of righting reflex, respiratory rate and convulsion [17].

\section{Induction of diabetes}

STZ-induced diabetes has been described as a useful experimental model to study the activity of hypoglycemic agents $[18,19]$. After an overnight fasting (deprived of food for 16 hours had been allowed free access to water), diabetes was induced in rats by intraperitoneal injection of STZ (Sigma, St. Louis, Mo. dissolved in 0.1 M sodium citrate buffer $\mathrm{pH} 4.5$ at a dose of $55 \mathrm{mg} / \mathrm{kg}$ body weight) [20]. After $6 \mathrm{~h}$ of STZ injection, rats were received $5 \%$ dextrose solution for the next $24 \mathrm{~h}$ to prevent STZ induced fatal hypoglycemia as a result of massive pancreatic insulin release after its administration [21]. Diabetes was confirmed $48 \mathrm{~h}$ after induction by measurement of tail vein blood glucose levels using glucose oxidase-peroxidase method. Diabetic rats were kept 7 days under standard laboratory condition for the stabilization of blood glucose levels [22]. After a week time for the development of diabetes, the rats with moderate diabetes having glucosuria and hyperglycemia (blood glucose range of above 15.6 $\mathrm{mM} / \mathrm{L}$ ) were considered as diabetic rats and were used for the further experiments. The change in the body weight experimental animals was observed throughout the treatment period.

\section{Experimental set up}

The rats were divided into seven groups with eight rats in each.

Group I: normal control rats received propylene glycol, orally $(5 \mathrm{~mL} /$ $\mathrm{kg})$.

Group II: Normal control rats were treated with CAMBA $(25 \mathrm{mg} / \mathrm{kg})$ [15].

Group III: Normal control rats were treated with CAMBA (50 mg/ $\mathrm{kg})$ [15].

Group IV: Diabetic control (STZ-induced diabetic rats, was given propylene glycol, orally $(5 \mathrm{~mL} / \mathrm{kg})$.

Group V: STZ-induced diabetic rats were treated with CAMBA (25 $\mathrm{mg} / \mathrm{kg}$ ) [15].

Group VI: STZ- induced diabetic rats were treated with CAMBA (50 $\mathrm{mg} / \mathrm{kg}$ ) [15].

Group VII: STZ-induced diabetic rats were treated with glibenclamide $(5 \mathrm{mg} / \mathrm{kg})[23]$

CAMBA and glibenclamide were suspended in propylene glycol and administered orally to its respective group animals for 28 days. The fasting blood glucose level and body weight were estimated every week $(0,7,14,21$ and 28 day). At the end of the fourth week, the fasted rats were sacrificed by cervical decapitation and the blood was collected using sodium fluoride as anticoagulant for determination of blood glucose. The liver and kidneys were dissected out, washed in ice-cold saline, patted dry and weighed.

\section{Blood sampling and biochemical assays}

The blood samples, centrifuged, and plasma was used freshly for estimation of plasma glucose [24]. Homeostatic index of insulin resistance (HOMA-IR), calculated by glucose $(\mathrm{mM}) \mathrm{x}$ insulin $(\mu \mathrm{U} /$ $\mathrm{ml} / 22.5$ [25]. Triacylglycerols [26], total cholesterol [27], HDLcholesterol [28], LDL-cholesterol [29] formula (LDL-cholesterol=total cholesterol - triacylglycerols/5-HDL-cholesterol). VLDL-cholesterol concentration [30] formula (vLDL-cholesterol=triacylglycerols/5). The atherogenic index $[\log (\mathrm{TG} / \mathrm{HDL}-\mathrm{C})]$ was also calculated [31]. A portion from liver, Kidney and/or heart was blotted, weighed and homogenized with methanol (3 volumes). It was used for the estimation of TBARs [32] and hydroperoxides [33]. Another portion of the tissues was homogenized with phosphate buffer saline and used for the estimation of GSH [34], GPx [35], Catalase (CAT) [36], SOD [37] and protein content [38].

\section{Measurement of lipid peroxidation}

A thiobarbituric acid reactive substances (TBARS) assay kit (ZeptoMetrix) was used to measure the lipid peroxidation products, malondialdehyde (MDA) equivalents [39]. In brief, liver, renal and heart tissues were homogenized with $0.1 \mathrm{~mol} / \mathrm{l}$ sodium phosphate buffer ( $\mathrm{pH}$ 7.4). One hundred microliters of homogenate were mixed with 2.5 $\mathrm{ml}$ reaction buffer (provided by the kit) and heated at $95^{\circ} \mathrm{C}$ for $60 \mathrm{~min}$. After the mixture had cooled, the absorbance of the supernatant was measured at $532 \mathrm{~nm}$ using a spectrophotometer. The lipid peroxidation products are expressed in terms of MDA equivalents.

\section{Measurement of antioxidant enzymes}

Superoxide dismutase (SOD), glutathione peroxidase (GPx) and Catalase (CAT) activities were determined using commercially available 
assay kits (Biodiagnostic). Briefly, liver, renal and heart tissues were weighed and homogenized with appropriate buffers (provided by the kits). The homogenates were then determined following the procedures provided by the respective manufacturers. The superoxide dismutase assay kit utilizes a tetrazolium salt for detection of superoxide radicals generated by red formazan dye reduction produced [40]. One unit (U) of SOD activity is defined as the amount of enzyme needed to exhibit $50 \%$ dismutation of the superoxide radical. The glutathione peroxidase assay kit measures GPx activity indirectly by a coupled reaction with glutathione reductase (GR) [41]. Oxidized glutathione, produced upon reduction of hydroperoxide by $\mathrm{GPx}$, is recycled to its reduced state by $\mathrm{GR}$ and NADPH. The oxidation of NADPH to $\mathrm{NADP}^{+}$is accompanied by a decrease in absorbance at $340 \mathrm{~nm}$. Under conditions in which the GPx activity is rate limiting, the rate of decrease in the $A_{340}$ is directly proportional to the GPx activity. One unit (U) of GPx activity is defined as the amount of enzyme that will cause the oxidation of $1.0 \mathrm{nmol}$ of $\mathrm{NADPH}$ to $\mathrm{NADP}^{+}$per minute at $25^{\circ} \mathrm{C}$. The specific activities of the various enzymes in the rat liver, renal and heart are expressed in U/ $\mathrm{mg}$ of the protein with the protein content determined as stated above.

The catalase assay kit utilizes the peroxidative function of CAT for determination of enzyme activity [42]. The method is based on the reaction of the enzyme with methanol in the presence of an optimal concentration of $\mathrm{H}_{2} \mathrm{O}_{2}$. The generated formaldehyde is assayed spectrophotometrically with 4-amino-3-hydrazino-5-mercapto-1,2,4triazole as the chromogen. One unit (U) of CAT activity is defined as the amount of enzyme that will cause the formation of $1.0 \mathrm{nmol}$ of formaldehyde per minute at $25^{\circ} \mathrm{C}$.

\section{Statistical analysis}

All data were expressed as mean \pm SD. All analyses utilized SPSS 15.0 statistical package for Windows (SPSS Inc., Chicago, IL). A oneway analysis of variance (ANOVA) was employed for comparisons of means of the different groups. A p-value 0.05 was accepted as statistically significant. Diabetic control rats were compared with normal control rats as well as CAMBA and glibenclamide treated diabetic rats were compared with diabetic control.

\section{Results}

\section{Chemistry}

The synthesis of the target compound caffeic acid methyl benzoate amide (CABMA) was achieved by the route depicted in Scheme 1.

Physicochemical and analytical data are listed in Table 1. IR (KBr, $\left.\mathrm{cm}^{-1}\right)$ CAMBA : $3332 \mathrm{~cm}^{-1}(\mathrm{OH}), 3133 \mathrm{~cm}^{-1}(\mathrm{NH}), 2962 \mathrm{~cm}^{-1}(\mathrm{CH}-$ arom.), $2854 \mathrm{~cm}^{-1}$ (CH-aliph.), 1715, $1685(2 \mathrm{C}=\mathrm{O}), 1520 \mathrm{~cm}^{-1}(\mathrm{C}=\mathrm{N})$. MS (m/z) CAMBA: $313\left(\mathrm{M}^{+}, 10.57 \%\right), 276$ (10.25\%), 224 (14.29\%), 183 (21.42\%), 137 (25.05\%), 97 (100\%), 55 (46.42\%). ${ }^{1} \mathrm{H}-\mathrm{NMR}$ (DMSO-d6) CAMBA: $2.4\left[\mathrm{~s}, 3 \mathrm{H}, \mathrm{COCH}_{3}\right], 6.1-6.2$ and 7.3-7.4 [d, $2 \mathrm{H}, \mathrm{CH}=\mathrm{CH}$, two trans-olefinic protons], 6.7-8.0 [m, 7H, Ar-H], $10.2[\mathrm{~s}, 1 \mathrm{H}, \mathrm{NH}]$. ${ }^{13} \mathrm{CNMR}\left(75 \mathrm{MHz}, \mathrm{CD}_{3} \mathrm{OD}\right)$ CAMBA:140.322(C-1), 121.392(C-1'), 123.303(C-2),115.529(C-2'), 130.500(C-3), 145.452(C-3'), 125.521(C$4), \quad 145.702\left(\mathrm{C}-4^{\prime}\right), \quad 129.859(\mathrm{C}-5), \quad 115.929\left(\mathrm{C}-5^{\prime}\right), \quad 114.663(\mathrm{C}-6)$, 119.102(C-6'), 165.021(C-7), 144.63(C-7'), 55.520(C-8), 109.21(C-8'), 199.47(C-9').

\section{Antidiabetic and Antioxidant Activity of CAMBA}

\section{Acute toxicity study}

In rats, oral administration of CAMBA at a dose of $1000 \mathrm{mg} / \mathrm{kg}$ did not produce any signs of toxicity and no animals were died up to
21 days. It showed that CAMBA was nontoxic in rats up to an oral dose of $1000 \mathrm{mg} / \mathrm{kg}$ b.w. Hyperactivity, sedation, loss of righting reflex, respiratory rate and convulsion were not observed at all used doses. Therefore, investigation of hypoglycemic and antioxidant activity was carried out using 25 and $50 \mathrm{mg} / \mathrm{kg}$ dose levels.

\section{Effect of CAMBA on body weight, blood glucose, insulin and HOMA-IR levels}

Administration of STZ significantly $(\mathrm{P}<0.01)$ reduced body weight in diabetic rats compared to normal control rats (Table 1). In diabetic rats, treatment of both doses of CAMBA and glibenclamide significantly $(\mathrm{P}<0.01)$ increased body weight compared to diabetic control rats. The blood glucose and HOMA-IR levels were significantly $(\mathrm{P}<0.01)$ increased but decreased the level of insulin $(\mathrm{P}<0.01)$ after the administration of STZ compared to the normal control rats. Oral treatment of CAMBA $25 \& 50 \mathrm{mg}$ and glibenclamide $(5 \mathrm{mg} / \mathrm{kg})$ decreased significantly $(\mathrm{P}<0.01)$ blood glucose and HOMA-IR level as well as the level of plasma insulin was significantly increased $(\mathrm{P}<0.01)$ in diabetic rats compared to diabetic control rats (Table 2).

\section{Effect of CAMBA on lipid profiles}

In STZ-induced diabetic rats, TC, TG, LDL, vLDL and atherogenic index levels were increased and HDL level was decreased significantly $(\mathrm{P}<0.01)$ compared to normal control rats. In diabetic rats, administration of CAMBA 25 and $50 \mathrm{mg} / \mathrm{kg}$ dose showed significant $(\mathrm{P}<0.01)$ reduction in elevated TC, TG, LDL, VLDL and atherogenic index levels compared to diabetic control rats. Also, a significantly $(\mathrm{P}<0.01)$ increased level of HDL was observed in diabetic rats treated with both doses of CAMBA and glibenclamide compared to diabetic control rats (Table 3 ).

\section{Antioxidant activity of CAMBA}

Table 4 shows the concentration of TBARS and hydroperoxides in liver, kidney and heart of control and experimental groups of rats. The levels of TBARS and hydroperoxides in diabetic rats were significantly higher $(\mathrm{P}<0.01)$ than control rats, whereas diabetic rats-treated with CAMBA 25 and $50 \mathrm{mg} / \mathrm{kg}$ and glibenclamide restored the altered values to the near normalcy. The antioxidant activity of CAMBA in liver, kidney and heart was studied in diabetic rats and the data were given in Table 5 . After the induction of diabetes by STZ, significantly $(\mathrm{P}<0.01)$ decreased levels of GSH, GPx, SOD and CAT were observed compared to normal control rats. These altered above antioxidant levels were reversed significantly $(\mathrm{P}<0.01)$ to near normal levels after the administration of CAMBA 25 and $50 \mathrm{mg} / \mathrm{kg}$ dose and glibenclamide 5 $\mathrm{mg} / \mathrm{kg}$ dose compared to diabetic control rats.

\section{Discussion}

Our study addresses the protective effect of CAMBA against STZinduced diabetic complications in rats. CAMBA was synthesized according the method adapted by Hussein, 2013 and its structure was proved on the basis of elemental analyses, IR, mass and ${ }^{1} \mathrm{HNMR}$ spectral data. The IR spectrum of compound CAMBA showed bands at $3332 \mathrm{~cm}^{-1}(\mathrm{OH}), 3133 \mathrm{~cm}^{-1}(\mathrm{NH}), 2962 \mathrm{~cm}^{-1}(\mathrm{CH}$-arom. $), 2854 \mathrm{~cm}^{-1}$ (CH-aliph.), 1715, $1685(2 \mathrm{C}=\mathrm{O}), 1520 \mathrm{~cm}^{-1}(\mathrm{C}=\mathrm{N})$. Mass spectrum of

\begin{tabular}{|c|c|c|c|c|c|c|}
\hline \multirow{3}{*}{ Compd. No. } & \multirow{3}{*}{ M.P. $\left[{ }^{\circ} \mathrm{C}\right]$} & \multirow{3}{*}{ Yield (\%) } & \multirow{3}{*}{$\begin{array}{l}\text { Mol. Formula } \\
\text { (Mol. Wt.) }\end{array}$} & \multirow{2}{*}{\multicolumn{3}{|c|}{\begin{tabular}{|l} 
Elemental analyses \\
Calcd./Found [\%] \\
\end{tabular}}} \\
\hline & & & & & & \\
\hline & & & & C & $\mathrm{H}$ & $\mathrm{N}$ \\
\hline CAMBA & $178-180$ & 77 & $\begin{array}{l}\mathrm{C}_{18} \mathrm{H}_{17} \mathrm{NO}_{5} \\
(313)\end{array}$ & $\begin{array}{l}65.17 \\
66.20\end{array}$ & $\begin{array}{l}4.79 \\
4.25\end{array}$ & $\begin{array}{l}4.47 \\
4.15\end{array}$ \\
\hline
\end{tabular}

Table 1: Physico-chemical properties and molecular formulae of CAMBA 
Citation: Hussein MA, Gobba NA (2013) CAMBA, a New Synthesized and Promising Protector against STZ-Induced Diabetic Complications in Rats. Med chem 3: 286293. doi:10.4172/2161-0444.1000153

\begin{tabular}{|c|c|c|c|}
\hline $\begin{array}{l}\text { Groups } \\
\text { Treatment/Dose }(\mathrm{mg} / \mathrm{mL})\end{array}$ & $\begin{array}{l}\text { Glucose } \\
(\mathrm{mM})\end{array}$ & $\begin{array}{l}\text { Insulin } \\
(\mu U / m l)\end{array}$ & $\begin{array}{c}\text { Homeostatic insulin } \\
\text { resistance index (HOMA-IR) }\end{array}$ \\
\hline Normal Control & $5.85 \pm 0.42$ & $3.10 \pm 0.11$ & $0.82 \pm 0.09$ \\
\hline Control + CAMBA (25mg/kg) & $5.48 \pm 0.61$ & $3.18 \pm 0.27$ & $0.79 \pm 0.05$ \\
\hline Control + CAMBA (50mg/kg) & $5.14 \pm 0.34$ & $3.33 \pm 0.15$ & $0.77 \pm 0.03$ \\
\hline Diabetic Control & $21.52 \pm 2.60^{* *}$ & $1.67 \pm 0.06^{* *}$ & $1.63 \pm 0.07^{* *}$ \\
\hline Diabetic + CAMBA (25mg/kg) & $8.15 \pm 2.07^{\star *}$ & $2.03 \pm 0.10^{* *}$ & $0.75 \pm 0.04^{*}$ \\
\hline Diabetic + CAMBA (50mg/kg) & $6.41 \pm 0.59^{* *}$ & $2.10 \pm 0.09^{* *}$ & $0.61 \pm 0.08^{* *}$ \\
\hline Diabetic + Glibenclamide $(5 \mathrm{mg} / \mathrm{kg})$ & $5.36 \pm 0.59^{* *}$ & $2.83 \pm 0.18^{\star \star}$ & $0.69 \pm 0.06^{* *}$ \\
\hline
\end{tabular}

Values are given as mean \pm SD for groups of eight animals each. Values are statistically significant at ${ }^{*} P<0.01$. Diabetic control rats were compared with normal control rats Experimental groups were compared with diabetic control

Table 2: Effect of CAMBA on body weight in normal and diabetic rats.

\begin{tabular}{|c|c|c|c|}
\hline $\begin{array}{l}\text { Groups } \\
\text { Treatment/Dose }(\mathrm{mg} / \mathrm{mL})\end{array}$ & $\begin{array}{l}\text { Glucose } \\
\text { (mM) }\end{array}$ & $\begin{array}{l}\text { Insulin } \\
(\mu \bigcup / m l)\end{array}$ & $\begin{array}{l}\text { Homeostatic insulin } \\
\text { resistance index (HOMA-IR) }\end{array}$ \\
\hline Normal Control & $5.85 \pm 0.42$ & $3.10 \pm 0.11$ & $0.82 \pm 0.09$ \\
\hline Control + CAMBA (25mg/kg) & $5.48 \pm 0.61$ & $3.18 \pm 0.27$ & $0.79 \pm 0.05$ \\
\hline Control + CAMBA (50mg/kg) & $5.14 \pm 0.34$ & $3.33 \pm 0.15$ & $0.77 \pm 0.03$ \\
\hline Diabetic Control & $21.52 \pm 2.60^{* *}$ & $1.67 \pm 0.06^{* *}$ & $1.63 \pm 0.07^{* *}$ \\
\hline Diabetic + CAMBA (25mg/kg) & $8.15 \pm 2.07^{\star *}$ & $2.03 \pm 0.10^{* *}$ & $0.75 \pm 0.04^{*}$ \\
\hline Diabetic + CAMBA (50mg/kg) & $6.41 \pm 0.59^{* *}$ & $2.10 \pm 0.09^{* *}$ & $0.61 \pm 0.08^{* *}$ \\
\hline Diabetic + Glibenclamide(5mg/kg) & $5.36 \pm 0.59^{* *}$ & $2.83 \pm 0.18^{* *}$ & $0.69 \pm 0.06^{* *}$ \\
\hline
\end{tabular}

Values are given as mean $\pm \mathrm{SD}$ for groups of eight animals each. Homeostatic index of insulin resistance (HOMA-IR), calculated by glucose $(\mathrm{mM}) \times \mathrm{insulin}(\mu \mathrm{U} / \mathrm{ml}) / 22.5$. Values are statistically significant at ${ }^{*} P<0.05 \&{ }^{* *} P<0.01$. Diabetic control rats were compared with normal control rats. Experimental groups were compared with the diabetic control rats

Table 3: Effect of CAMBA on plasma glucose, insulin and HOMA-IR in control and experimental groups of rats.

\begin{tabular}{|c|c|c|c|c|c|c|}
\hline $\begin{array}{l}\text { Groups } \\
\text { Treatment/Dose }(\mathrm{mg} / \mathrm{mL})\end{array}$ & $\begin{array}{c}\text { TG } \\
(\mathrm{mg} / \mathrm{dl})\end{array}$ & $\begin{array}{c}\mathrm{TC} \\
(\mathrm{mg} / \mathrm{dl})\end{array}$ & $\begin{array}{l}\mathrm{HDL}-\mathrm{C} \\
(\mathrm{mg} / \mathrm{dl})\end{array}$ & $\begin{array}{l}\text { LDL-C } \\
\text { (mg/dl) }\end{array}$ & $\begin{array}{r}\mathrm{vLDL}-\mathrm{C} \\
(\mathrm{mg} / \mathrm{dl})\end{array}$ & Atherogenic index \\
\hline Normal Control & $83.92 \pm 4.63$ & $102.73 \pm 5.52$ & $37.6 \pm 5.84$ & $48,35 \pm 4.95$ & $16.78 \pm 2.6$ & $0.348 \pm 0.078$ \\
\hline Control + CAMBA $(25 \mathrm{mg} / \mathrm{kg})$ & $79.27 \pm 5.81$ & $95.18 \pm 6.22$ & $34.21 \pm 4.69$ & $45.12 \pm 7.24$ & $15.85 \pm 4.10$ & $0.364 \pm 0.065$ \\
\hline Control + CAMBA $(25 \mathrm{mg} / \mathrm{kg})$ & $76.56 \pm 6.09$ & $90.39 \pm 4.64$ & $39.07 \pm 6.24$ & $36.00 \pm 4.71$ & $15.31 \pm 3.6$ & $0.292 \pm 0.049$ \\
\hline Diabetic Control & $157.34 \pm 9.77^{\star *}$ & $141.53 \pm 7.04^{* *}$ & $24.33 \pm 5.46^{\star *}$ & $85.55 \pm 4.94^{* *}$ & $31.48 \pm 6.9^{\star *}$ & $0.810 \pm 0.083^{* *}$ \\
\hline Diabetic +CAMBA $(25 \mathrm{mg} / \mathrm{kg})$ & $106.48 \pm 6.19^{\star *}$ & $137.50 \pm 5.26^{* *}$ & $27.18 \pm 4.50^{* *}$ & $89.02 \pm 6.11^{* *}$ & $21.29 \pm 3.4^{* *}$ & $0.593 \pm 0.046^{*}$ \\
\hline Diabetic +CAMBA $(25 \mathrm{mg} / \mathrm{kg})$ & $86.25 \pm 4.02^{* *}$ & $94.67 \pm 3.44^{* *}$ & $33.75 \pm 6.38^{* *}$ & $43.67 \pm 4.38^{* *}$ & $17.25 \pm 4.2^{* \star}$ & $0.407 \pm 0.037^{\star *}$ \\
\hline Diabetic + Glibenclamide $(5 \mathrm{mg} / \mathrm{kg})$ & $77.28 \pm 6.86^{\star *}$ & $92.58 \pm 8.15^{\star *}$ & $35.02 \pm 7.53^{* *}$ & $42.10 \pm 5.72^{* *}$ & $15.45 \pm 3.6^{\star *}$ & $0.344 \pm 0.026^{\star *}$ \\
\hline
\end{tabular}

Values represent the mean $\pm \mathrm{SE}(\mathrm{n}=8)$. Diabetic control rats were compared with normal control rats. Experimental groups were compared with the diabetic control rats $\operatorname{LDL}-\mathrm{C}(\mathrm{mg} / \mathrm{dl})=\mathrm{TC}-\mathrm{HDL}-[\mathrm{TG} / 5], \quad \mathrm{VLDL}-\mathrm{C}(\mathrm{mg} / \mathrm{dl})=[$ Triglycerides/5], Atherogenic index $=\log (\mathrm{TG} / \mathrm{HDL}-\mathrm{C})$

- *Significantly different from control group at $p<0.05$

- ${ }^{* *}$ Significantly different from control group at $p<0.01$

Table 4: Effect of CAMBA on plasma triglyceride (TG), total Cholesterol (TC), HDL-cholesterol (HDL-C), LDL- cholesterol (LDLC), vLDL- cholesterol (vLDLC) and atherogenic index in control and experimental groups of rats.

\begin{tabular}{|c|c|c|c|c|c|c|}
\hline \multirow{2}{*}{$\begin{array}{l}\text { Groups } \\
\text { Treatment/Dose (mg/mL) }\end{array}$} & \multicolumn{2}{|c|}{ Liver } & \multicolumn{2}{|c|}{ Kidney } & \multicolumn{2}{|c|}{ Heart } \\
\hline & $\begin{array}{c}\text { TBARs } \\
\mathrm{mM} / 100 \mathrm{~g} . \text { tissue }\end{array}$ & $\begin{array}{c}\mathrm{HP} \\
\mathrm{mM} / 100 \mathrm{~g} . \text { tissue }\end{array}$ & $\begin{array}{c}\text { TBARs } \\
\mathrm{mM} / 100 \mathrm{~g} . \text { tissue }\end{array}$ & $\begin{array}{c}\mathrm{HP} \\
\mathrm{mM} / 100 \mathrm{~g} . \text { tissue }\end{array}$ & $\begin{array}{c}\text { TBARs } \\
\mathrm{mM} / 100 \mathrm{~g} . \text { tissue }\end{array}$ & $\begin{array}{c}\mathrm{HP} \\
\mathrm{mM} / 100 \mathrm{~g} . \text { tissue }\end{array}$ \\
\hline Normal Control & $0.67 \pm 0.029$ & $48.70 \pm 2.97$ & $0.46 \pm 0.051$ & $29.65 \pm 3.44$ & $0.52 \pm 0.042$ & $36.18 \pm 6.05$ \\
\hline Control + CAMBA (25mg/kg) & $0.62 \pm 0.013$ & $34.08 \pm 4.11$ & $0.40 \pm 0.048$ & $28.16 \pm 3.62$ & $0.50 \pm 0.036$ & $34.28 \pm 4.11$ \\
\hline Control + CAMBA (50mg/kg) & $0.60 \pm 0.019$ & $25.69 \pm 6.04$ & $0.39 \pm 0.062$ & $25.93 \pm 4.07$ & $0.44 \pm 0.092$ & $30.42 \pm 5.00$ \\
\hline Diabetic Control & $1.36 \pm 0.028^{* *}$ & $76.28 \pm 5.53^{* *}$ & $0.89 \pm 0.076^{* *}$ & $64.33 \pm 5.16^{\star *}$ & $0.84 \pm 0.045^{\star *}$ & $74.16 \pm 6.03^{* *}$ \\
\hline Diabetic + CAMBA (25mg/kg) & $0.67 \pm 0.017^{* *}$ & $42.55 \pm 2.39^{* *}$ & $0.50 \pm 0.034^{* *}$ & $34.28 \pm 4.05^{\star *}$ & $0.59 \pm 0.080^{* *}$ & $34.48 \pm 2.76^{* *}$ \\
\hline Diabetic + CAMBA (50mg/kg) & $0.60 \pm 0.035^{\star *}$ & $41.49 \pm 3.27^{\star *}$ & $0.44 \pm 0.047^{* *}$ & $28.54 \pm 3.70^{* *}$ & $0.54 \pm 0.045^{\star *}$ & $31.00 \pm 2.98^{* *}$ \\
\hline Diabetic + Glibenclamide (5mg/kg) & $0.63 \pm 0.091^{* *}$ & $46.58 \pm 4.74^{\star *}$ & $0.55 \pm 0.061^{* *}$ & $32.53 \pm 5.58^{\star *}$ & $0.53 \pm 0.027^{* *}$ & $39.07 \pm 6.15^{\star *}$ \\
\hline
\end{tabular}

Values represent the mean \pm SE $(n=8)$. Diabetic control rats were compared with normal control rats. Experimental groups were compared with the diabetic control rats - ${ }^{* *}$ Significantly different from control group at $p<0.01$

Table 5: Effect of CAMBA on liver, kidney and heart TBARs and HP in control and experimental groups of rats.

compound CAMBA exhibited molecular ion peak $313\left(\mathrm{M}^{+}, 10.57 \%\right)$ with base peak at $97(100 \%)$ and other significant peaks at $276(10.25 \%)$, 224 (14.29\%), 183 (21.42\%), 137 (25.05\%) and 55 (46.42\%). ${ }^{1} \mathrm{HNMR}$ spectrum of compound CAMBA in (DMSO- $\mathrm{d}_{6}$ ) exhibited signals at $2.4\left[\mathrm{~s}, 3 \mathrm{H}, \mathrm{COCH}_{3}\right], 6.2[\mathrm{~d}, 2 \mathrm{H}, \mathrm{CH}=\mathrm{CH}$, two trans-olefinic protons], 6.7-8.0 [m, 7H, Ar-H], $10.2[\mathrm{~s}, 1 \mathrm{H}, \mathrm{NH}]$. Also, ${ }^{13} \mathrm{C}-\mathrm{NMR}$ spectrum of compound $\mathrm{CAMBA}$ in $\left(\mathrm{CD}_{3} \mathrm{OD}\right)$ exhibited signals at $144.63\left(\mathrm{C}-7^{\prime}\right)$,
109.21(C-8') and 199.47(C-9') indecated that the precence of double bond betwen $\mathrm{C}^{-7^{\prime}}$ and $\mathrm{C}-\mathrm{8}^{\prime}$ as well as precense of $(\mathrm{C}=\mathrm{O})$ group at $(\mathrm{C}$ $\left.9^{\prime}\right)$.

In acute toxicity study, CAMBA did not show significant toxicity signs when observed for the parameters during the first four hours and followed by daily observations for 21 days and no mortality was also 


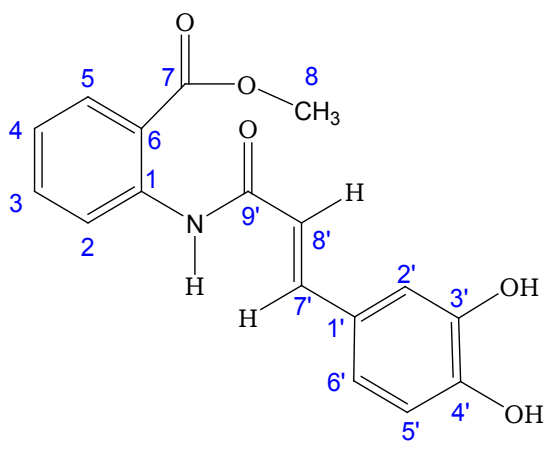

Figure 2: Caffeic acid methyl benzoate amide (CAMBA) [15]

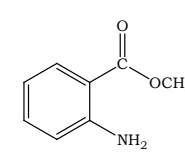

Methyl anthranilate

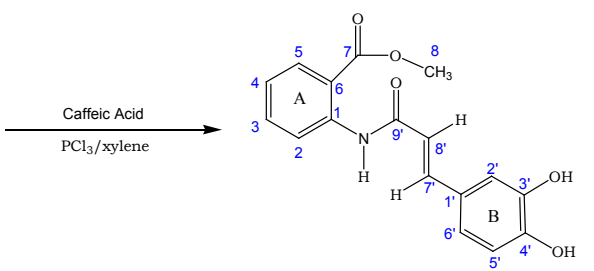

Caffeic acid methyl benzoate amide (CAMBA) observed, the drug was found to be safe at $(400,800$ and $1000 \mathrm{mg} / \mathrm{kg}$ b.wt).

The present study was conducted to evaluate the beneficial effects of CAMBA on antioxidant status in STZ-induced diabetic rats. The preliminary studies conducted by this work revealed the non-toxic nature of CAMBA on normal rats. Although no literature data have given any insight into the possible toxicological potentials of CAMBA, except for antioxidant and anti-inflammatory activity of CAMBA [15]. Hussein [15], reported the structure antioxidant relationship of CAMBA as well as its $\mathrm{LD}_{50}$ which equal $1135 \mathrm{mg} / \mathrm{kg}$. b.w. In fact, administration of CAMBA at 25 and $50 \mathrm{mg} / \mathrm{kg}$.b.w. did not cause evident signs of liver, renal and heart injury as indicated by the activities of tissue oxidative stress biomarkers.

STZ [2-deoxy-2- (3-methyl-3-nitrosoureido)-D-glucopyranose] is commonly used to induce experimental diabetes in animals [6]. STZ -induced diabetes may be due to vitiate glucose oxidation and reduction of insulin biosynthesis and secretion. The toxicity of STZ is due to DNA alkylation of its methyl nitrosourea moiety mainly at 6 $O$-position of guanine [7]. The transfer of methyl group from STZ to the DNA molecule causes damage which results in fragmentation of DNA and functional defects of the beta cells. Moreover, STZ is potential to act as an intracellular nitric oxide (NO) donor and generates reactive oxygen species (ROS). The synergistic action of both NO and ROS may also contribute to DNA fragmentation and other deleterious changes caused by STZ [8].

Single dose of STZ (55 mg/kg.b.w. rats) in sterile citrate buffer (e.g. $\mathrm{pH}$ 4.5, $0.1 \mathrm{M}$ ) administered intraperitoneally [20]. The rats were allowed to resume feeding and drinking of $5 \%$ glucose solution for 30 minutes after the STZ administration to avoid the exposure of rats to a sudden drop in the level of insulin. Diabetes develops gradually and assessed after a seven days. In the present study, a plasma glucose level of about $13.8 \mathrm{mM}$ indicates the induction of diabetes mellitus.

This model permits the evaluation of the effect of CAMBA in an animal without the interference of the side effects induced by STZ [43]. In our study, elevated blood glucose level and decreased insulin level were observed in STZ-induced diabetic rats and it may be due to above stated mechanism of STZ. Oral administration of CAMBA 25 , $50 \mathrm{mg} / \mathrm{kg}$ and glibenclamide to the diabetic rats significantly reduced blood glucose level with compared to diabetic control rats. Also, the decreased insulin and insulin resistance levels were noticed in diabetic rats compared to normal control rats which directly support and represent STZ-mediated $\beta$-cells destruction or damage. In diabetic rats, treatment of CAMBA and glibenclamide increased the insulin and insulin resistance levels compared to diabetic control rats. Hence, the hypoglycemic activity of CAMBA may be due to its protective action against STZ-mediated damage to the pancreatic $\beta$-cells and also possibly because of regeneration of damaged beta cell or increased insulin release or secretion.

Muscle wasting is an unintentional loss of body weight due to accelerated muscle proteolysis, resulting in loss of body cell mass. Insulin is an important regulator of protein synthesis and proteolysis in skeletal muscle. Insulin resistance or deficiency produces impaired muscle protein turnover and muscle wasting. The uncontrolled diabetes is associated with severe muscle wasting [44]. In this study, STZ-induced diabetes is characterized by severe loss in body weight [45] and this was also seen in the present study. CAMBA 25, $50 \mathrm{mg} /$ $\mathrm{kg}$ and glibenclamide administration controlled this loss in body weight. However, it did not normalize the body weight completely as it remained lesser than normal control rats. The decrease in body weight observed in diabetic rats might be the result of protein wasting due to unavailability of carbohydrate for utilization as an energy source [22].

In recent years, considerable interest has been directed towards the investigation of plasma lipids and lipoproteins pattern in diabetes mellitus due to the fact that abnormal lipid level leads to the development of coronary artery disease in diabetic patients [46]. Reduced insulin secretion and defect in insulin function results in enhanced metabolism of lipids from adipose tissue to the plasma. Impairment in insulin sensitivity due to high concentration of lipids in the cells is responsible for the elevated cardiovascular risk in diabetes mellitus [47]. Thus, the altered lipid and lipoprotein pattern observed in diabetic rats could be due to defect in insulin secretion and/or action. Accumulation of cholesterol and phospholipids in liver due to elevated plasma free fatty acids has been reported in diabetic rats [48]. Hyperglycemia is an important contributor for the cardiovascular diseases (CVD) risk.

The animal studies revealed that hyperglycemia produces glycation and peroxidation of proteins which cause damage to the arterial walls [49]. The prevalence of all forms of CVD is 2-8 folds higher in diabetic person compared to non-diabetic person. The accelerated coronary heart disease (CHD) has emerged as a leading cause of morbidity and mortality in diabetic patients in the worldwide [50]. The vascular diseases occurred in diabetes due to disturbance in lipoprotein metabolism which causes acceleration of atherosclerosis [48]

In the present study, increases in plasma TC, TG, LDL, vLDL and atherogenic index and reduced level of HDL levels were observed in STZ- induced diabetic rats. It is interesting to note that CAMBA did not only lower the TC, TG, LDL and vLDL levels, but also enhanced the cardio protective lipid HDL and atherogenic index of the diabetic rats after 30 days of treatment. The increased in HDL-cholesterol is a desirable feature. In addition, the reductions in TC, TG and LDLcholesterol could be beneficial in preventing diabetic complications as well as improving lipid metabolism in diabetics [51]. This would 
definitely reduce the incidence of coronary events being the major cause of morbidity and deaths in diabetes subjects [52]. HDL-C transports cholesterol from peripheral tissues to the liver, thereby reducing the amount stores in tissue and decreasing the likelihood of getting atherosclerotic plagues [53].

This study indicated that CAMBA $25,50 \mathrm{mg} / \mathrm{kg}$ significantly reduced TC, TG, LDL, vLDL and atherogenic index and increased HDL concentrations (Table 3 ), which could be due to stimulating effect on insulin secretion from pancreatic $\beta$ - cells (Table 2). The possible mechanism by which CAMBA can exert lipid lowering activities may be explained by decreasing the cholesterol biosynthesis, particularly by decreasing the activity of hydroxyl-3-methylglutaryl-coenzyme A (HMG-CoA) reductase or by reducing the NADPH required for cholesterol synthesis and/or by stimulating glucose utilization [54]. In our study, it has been proposed that CAMBA and glibenclamide acted in a similar way by increasing insulin production in STZ-induced diabetic rats and lowering TG level by activation of the enzyme lipoprotein lipase, because insulin activates lipoprotein lipase [55].

Several studies have demonstrated the involvement of free radicals in the genesis of diabetes mellitus and their role in the induction of lipid peroxidation during diabetes [56]. It has been reported that in diabetes mellitus, oxygen free radicals are generated by stimulating $\mathrm{H}_{2} \mathrm{O}_{2}$ in vitro as well as in vivo and in pancreatic $\beta$-cells [56]. The increased lipid peroxidation in the diabetic animals may be due to the observed remarkable increase in the concentration of TBARs and HPs (lipid peroxidative markers) in the liver and kidney of diabetic rats [57]. Moreover, drastic reduction of in vivo antioxidant enzymes level in various tissues was reported in diabetic condition [57]. In our study, decreased levels of liver and kidney GSH, GPx, SOD and CAT as well as increased level of TBARs and HPs were observed in liver, renal and heart tissues of STZ-induced diabetic rats compared to normal control rats (Table 4 ). The reduction of above enzymes directly reflects the oxidative stress in diabetic rats and these enzyme level changes may be due to generation of free radicals by auto-oxidation of glucose, glycosylation in hyperglycemic condition as well as STZ mediated generation of ROS by its NO donor property to the intracellular molecules. In the present study, increased GSH, GPx, SOD and CAT levels (Table 5) as well as reduced TBARs and HPs levels were noticed in diabetic rats after the administration of both doses of CAMBA 25, $50 \mathrm{mg} / \mathrm{kg}$ and glibenclamide in liver and kidney. The above action represents the antioxidant property of CAMBA in diabetic condition and hence, CAMBA possesses a potential to reduce or prevent the diabetic complications.

Antioxidant activity mainly involves two major mechanisms: electron transfer (ET) and hydrogen atom transfer (HAT). Thus it is of interest to evaluate which one of these mechanisms is favored by CAMBA. CAMBA are relatively active quenchers of free radicals and singlet oxygen, like all phenolic compounds [58]. In vitro antioxidant activity of CAMBA depends on its structure feature [15]. The structural requirement considered essential for effective radical scavenging by CAMBA is the presence of $P$-dihydroxyl groups in $\mathrm{B}$ ring and conjugated double bond. The presence of double bond between $\mathrm{B}$ ring and carbonyl group in CAMBA makes the electrons more delocalized to form quinone structure which possesses electron donating properties and is a radical target [15]. The results of Hussein [15] indicated that antioxidant activity of CAMBA due to the above two mechanisms electron transfer (ET) and hydrogen atom transfer (HAT). On the other hand, a consistent increase of antioxidant activity is reported with CAMBA where the carbonyl is indirectly linked to the aromatic ring [59]. Spacing between the carbonyl group and catechol aromatic ring (B) induces increase in potency as shown with CAMBA as well as decreasing the space linked of amide group with the noncatechol aromatic ring (A) increases the antioxidant activity.

Antioxidant and protective effect of newly synthesized CAMBA against STZ-induced diabetic complications in rats has not been reported earlier to our knowledge, and this study is perhaps the first observation of its kind. Conclusively, our observations have clearly demonstrated that the CAMBA significant antioxidant and antihyperglycaemic activity due to its possible multiple effect involving both pancreatic and extra-pancreatic mechanism. CAMBA possessed a capability to inhibit the lipid peroxidation and activate the antioxidant markers (GSH, GPx, SOD and CAT) in diabetes. The ability to reduce oxidative stress may help to prevent diabetic complications. More studies are needed to prove its medicinal and biological importance which may pave the way for possible therapeutic applications.

\begin{tabular}{|c|c|c|c|c|c|c|c|c|c|c|c|c|}
\hline \multirow[b]{2}{*}{$\begin{array}{l}\text { Groups } \\
\text { Treatment/Dose (mg/ } \\
\mathrm{mL} \text { ) }\end{array}$} & \multicolumn{4}{|c|}{ Liver } & \multicolumn{4}{|c|}{ Kidney } & \multicolumn{4}{|c|}{ Heart } \\
\hline & $\begin{array}{c}\text { GSH } \\
\text { mg/100g. } \\
\text { tissue }\end{array}$ & $\begin{array}{c}\text { GPX } \\
\text { U/mg. } \\
\text { protein }\end{array}$ & $\begin{array}{c}\text { SOD } \\
\text { U/mg. } \\
\text { protein }\end{array}$ & $\begin{array}{c}\text { CAT } \\
\text { U/mg. } \\
\text { protein }\end{array}$ & $\begin{array}{c}\text { GSH } \\
\mathrm{mg} / 100 \mathrm{~g} . \\
\text { tissue }\end{array}$ & $\begin{array}{c}\text { Gpx } \\
\text { U/mg. } \\
\text { protein }\end{array}$ & $\begin{array}{c}\text { SOD } \\
\text { U/mg. } \\
\text { protein }\end{array}$ & $\begin{array}{c}\text { CAT } \\
\text { U/mg. } \\
\text { protein }\end{array}$ & $\begin{array}{c}\text { GSH } \\
\mathrm{mg} / 100 \mathrm{~g} . \\
\text { tissue }\end{array}$ & $\begin{array}{c}\text { GPx } \\
\text { U/mg. } \\
\text { protein }\end{array}$ & $\begin{array}{l}\text { SOD } \\
\mathrm{mg} / 100 \mathrm{~g} . \\
\text { tissue }\end{array}$ & $\begin{array}{c}\text { CAT } \\
\text { mg/100g. } \\
\text { tissue }\end{array}$ \\
\hline Normal Control & $\begin{array}{r}142.34 \\
\pm 5.261\end{array}$ & $\begin{array}{l}17.14 \\
\pm 2.05\end{array}$ & $\begin{array}{r}13.89 \\
\pm 3.71\end{array}$ & $\begin{array}{r}65.19 \\
\pm 4.71\end{array}$ & $\begin{array}{l}101.00 \\
\pm 8.38\end{array}$ & $\begin{array}{c}8.06 \\
\pm 1.43\end{array}$ & $\begin{array}{r}10.44 \\
\pm 2.71\end{array}$ & $\begin{array}{l}43.28 \\
\pm 3.48\end{array}$ & $\begin{array}{l}115.48 \\
\pm 9.04\end{array}$ & $\begin{array}{r}13.59 \\
\pm 2.50\end{array}$ & $\begin{array}{c}9.08 \\
\pm 1.91\end{array}$ & $\begin{array}{l}27.46 \\
\pm 2.83\end{array}$ \\
\hline $\begin{array}{l}\text { Control + CAMBA } \\
(25 \mathrm{mg} / \mathrm{kg})\end{array}$ & $\begin{array}{l}139.68 \\
\pm 7.90\end{array}$ & $\begin{array}{r}16.05 \\
\pm 3.22\end{array}$ & $\begin{array}{r}12.44 \\
\pm 1.75\end{array}$ & $\begin{array}{l}60.34 \\
\pm 5.38\end{array}$ & $\begin{array}{l}98.07 \\
\pm 5.40\end{array}$ & $\begin{array}{c}8.11 \\
\pm 2.07\end{array}$ & $\begin{array}{r}10.25 \\
\pm 3.13\end{array}$ & $\begin{array}{l}46.08 \\
\pm 5.23\end{array}$ & $\begin{array}{l}114.50 \\
\pm 6.37\end{array}$ & $\begin{array}{r}13.33 \\
\pm 2.01\end{array}$ & $\begin{array}{r}10.26 \\
\pm 1.79\end{array}$ & $\begin{array}{l}29.04 \\
\pm 5.26\end{array}$ \\
\hline $\begin{array}{l}\text { Control + CAMBA } \\
(50 \mathrm{mg} / \mathrm{kg})\end{array}$ & $\begin{array}{l}140.57 \\
\pm 8.11\end{array}$ & $\begin{array}{r}18.10 \\
\pm 4.06\end{array}$ & $\begin{array}{r}13.06 \\
\pm 2.30\end{array}$ & $\begin{array}{r}64.35 \\
\pm 7.11\end{array}$ & $\begin{array}{r}104.71 \\
\pm 10.59\end{array}$ & $\begin{aligned} & 8.98 \\
\pm & 1.90\end{aligned}$ & $\begin{array}{r}11.17 \\
\pm 2.39\end{array}$ & $\begin{array}{r}46.69 \\
\pm 7.08\end{array}$ & $\begin{array}{r}117.92 \\
\pm 10.25\end{array}$ & $\begin{array}{r}14.05 \\
\pm 2.67\end{array}$ & $\begin{array}{r}12.74 \\
\pm 3.08\end{array}$ & $\begin{array}{l}28.11 \\
\pm 3.29\end{array}$ \\
\hline Diabetic Control & $\begin{array}{c}87.45 \\
\pm 5.08^{\star \star}\end{array}$ & $\begin{array}{c}7.44 \\
\pm 1.15^{\star \star}\end{array}$ & $\begin{aligned} & 4.19 \\
\pm & 1.33^{\star *}\end{aligned}$ & $\begin{array}{c}37.94 \\
\pm 4.38^{\star *}\end{array}$ & $\begin{array}{l}55.06 \\
\pm 4.38\end{array}$ & $\begin{aligned} & 4.56 \\
\pm & 0.58^{\star *}\end{aligned}$ & $\begin{aligned} & 5.94 \\
\pm & 1.47^{\star \star}\end{aligned}$ & $\begin{array}{c}27.93 \\
\pm 4.66^{\star \star}\end{array}$ & $\begin{array}{c}76.82 \\
\pm 6.08^{* *}\end{array}$ & $\begin{aligned} & 5.99 \\
\pm & 1.85^{\star *}\end{aligned}$ & $\begin{aligned} & 6.55 \\
\pm & 1.13^{\star *}\end{aligned}$ & $\begin{aligned} & 15.95 \\
\pm & 2.18^{\star \star}\end{aligned}$ \\
\hline $\begin{array}{l}\text { Diabetic + CAMBA } \\
(25 \mathrm{mg} / \mathrm{kg})\end{array}$ & $\begin{array}{c}122.73 \\
\pm 8.46^{\star *}\end{array}$ & $\begin{array}{c}11.82 \\
\pm 2.00^{\star \star}\end{array}$ & $\begin{aligned} & 7.86 \\
\pm & 2.35^{\star *}\end{aligned}$ & $\begin{array}{l}50.08 \\
\pm 6.26\end{array}$ & $\begin{array}{l}75.97 \\
\pm 6.84\end{array}$ & $\begin{aligned} & 6.27 \\
\pm & 1.08^{* *}\end{aligned}$ & $\begin{aligned} & 7.16 \\
\pm & 0.57^{\star \star}\end{aligned}$ & $\begin{array}{c}35.00 \\
\pm 4.86^{* *}\end{array}$ & $\begin{array}{c}84.26 \\
\pm 4.75^{\star *}\end{array}$ & $\begin{aligned} & 8.22 \\
\pm & 2.04^{\star \star}\end{aligned}$ & $\begin{array}{c}7.72 \\
\pm 1.94^{* *}\end{array}$ & $\begin{array}{c}22.49 \\
\pm 3.30^{\star *}\end{array}$ \\
\hline $\begin{array}{l}\text { Diabetic + CAMBA } \\
(50 \mathrm{mg} / \mathrm{kg})\end{array}$ & $\begin{array}{r}138.83 \\
\pm 7.93^{* *}\end{array}$ & $\begin{array}{c}15.77 \\
\pm 2.57^{* *}\end{array}$ & $\begin{array}{c}11.46 \\
\pm 3.24^{* *}\end{array}$ & $\begin{array}{r}59.63 \\
\pm 4.81\end{array}$ & $\begin{array}{l}89.44 \\
\pm 7.65\end{array}$ & $\begin{array}{c}9.63 \\
\pm 2.48^{* *}\end{array}$ & $\begin{array}{c}10.39 \\
\pm 2.71^{* *}\end{array}$ & $\begin{array}{c}41.60 \\
\pm 4.22^{* *}\end{array}$ & $\begin{array}{c}104.13 \\
\pm 7.38^{* *}\end{array}$ & $\begin{array}{c}11.29 \\
\pm 2.41^{* *}\end{array}$ & $\begin{array}{c}10.55 \\
\pm 2.03^{* *}\end{array}$ & $\begin{array}{c}25.37 \\
\pm 4.02^{\star *}\end{array}$ \\
\hline $\begin{array}{l}\text { Diabetic + } \\
\text { Glibenclamide }(5 \mathrm{mg} / \mathrm{kg})\end{array}$ & $\begin{array}{c}128.44 \\
\pm 6.50^{* *}\end{array}$ & $\begin{array}{c}12.85 \\
\pm 1.48^{\star \star}\end{array}$ & $\begin{aligned} & 9.59 \\
\pm & 2.18^{* *}\end{aligned}$ & $\begin{array}{r}54.16 \\
\pm 3.99\end{array}$ & $\begin{array}{r}80.39 \\
\pm 5.07\end{array}$ & $\begin{aligned} & 8.15 \\
\pm & 1.83^{\star *}\end{aligned}$ & $\begin{aligned} & 9.80 \\
\pm & 2.11^{\star *}\end{aligned}$ & $\begin{aligned} & 30.85 \\
\pm & 2.79^{\star \star}\end{aligned}$ & $\begin{array}{c}90.44 \\
\pm 8.06^{* *}\end{array}$ & $\begin{aligned} & 9.08 \\
\pm & 2.11^{* *}\end{aligned}$ & $\begin{array}{c}9.12 \\
\pm 1.60^{* *}\end{array}$ & $\begin{aligned} & 19.70 \\
\pm & 3.46^{\star *}\end{aligned}$ \\
\hline
\end{tabular}

Values represent the mean $\pm S E(n=8)$. Diabetic control rats were compared with normal control rats. Experimental groups were compared with the diabetic control rats. Activity is expressed as: $50 \%$ of inhibition of epinephrine auto oxidation per min for SOD; $\mu$ moles of hydrogen peroxide decomposed per min. for catalase; $\mu$ moles of glutathione oxidized per min. for GPx. ${ }^{* *}$ significantly different from control group at $p<0.01$

Table 6: Effect of CAMBA on liver, kidney and heart GSH, GPx, SOD and CAT in control and experimental groups of rats. 
Citation: Hussein MA, Gobba NA (2013) CAMBA, a New Synthesized and Promising Protector against STZ-Induced Diabetic Complications in Rats. Med chem 3: 286293. doi:10.4172/2161-0444.1000153

\section{Acknowledgement}

Thanks to Dr: Yasser H. Mohamed (Inorganic laboratory, Central laboratory, Greater Cairo Drinking Water Company, Fustat water treatment plant, Egypt), Dr. Wael M. Kamel (National Research Centre, Dokki, Egypt) for helping me in animal care and statistical analysis and management the analyses of the study.

\section{References}

1. Macfarlane DP, Paterson KR, Fisher M (2007) Oral antidiabetic agents as cardiovascular drugs. Diabetes Obes Metab 9: 23-30

2. Olatunji LA, Soladoye AO (2007) Increased magnesium intake prevents hyperlipidemia and insulin resistance and reduces lipid peroxidation in fructosefed rats. Pathophysiology 14: 11-15.

3. Sima AA, Kamiya $H$ (2006) Diabetic neuropathy differs in type 1 and type 2 diabetes. Ann N Y Acad Sci 1084: 235-249.

4. Ritz E (2006) Diabetic nephropathy. Saudi J Kidney Dis Transpl 17: 481-490.

5. Maritim AC, Sanders RA, Watkins JB 3rd (2003) Diabetes, oxidative stress, and antioxidants: a review. J Biochem Mol Toxicol 17: 24-38.

6. Al-Attar AM, Zari TA (2007) Modulatory Effects of Ginger and Clove Oils on Physiological Responses in Streptozotocin-Induced Diabetic Rats. Int J Pharmacol 3: 34-40.

7. Szkudelski T (2001) The mechanism of alloxan and streptozotocin action in B cells of the rat pancreas. Physiol Res 50: 537-546.

8. Lenzen S (2008) The mechanisms of alloxan- and streptozotocin-induced diabetes. Diabetologia 51: 216-226.

9. Guo W, Kong E, Meydani M (2009) Dietary polyphenols, inflammation, and cancer. Nutr Cancer 61: 807-810.

10. Hwang JT, Kwon DY, Yoon SH (2009) AMP-activated protein kinase: a potential target for the diseases prevention by natural occurring polyphenols. N Biotechnol 26: 17-22.

11. Wongcharoen W, Phrommintikul A (2009) The protective role of curcumin in cardiovascular diseases. Int J Cardiol 133: 145-151.

12. Michaluart $P$, Masferrer JL, Carothers AM, Subbaramaiah K, Zweifel BS, et al. (1999) Inhibitory effects of caffeic acid phenethyl ester on the activity and expression of cyclooxygenase-2 in human oral epithelial cells and in a rat model of inflammation. Cancer Res 59: 2347-2352.

13. Liao HF, Chen YY, Liu JJ, Hsu ML, Shieh HJ, et al. (2003) Inhibitory effect of caffeic acid phenethyl ester on angiogenesis, tumor invasion, and metastasis. J Agric Food Chem 51: 7907-7912.

14. Farooqui T, Farooqui A (2010) Molecular Mechanism Underlying the Therapeutic Activities of Propolis: A Critical Review. Curr Nutr Food Sci 6: 188199.

15. Hussein MA (2013) Synthesis, anti-inflammatory, and structure antioxidant activity relationship of novel 4-quinazoline. Med Chem Res 22: 4641-4653.

16. Hussein MA (2012) Synthesis of some novel triazoloquinazolines and triazinoquinazolines and their evaluation for anti-inflammatory activity. Med Chem Res 21:1876-1886.

17. Ghosh M, Razmovski V (1994) Fundamentals of experimental pharmacology. Scientific Book Agency Kolkatta. 116-118.

18. Junod A, Lambert AE, Stauffacher W, Renold AE (1969) Diabetogenic action of streptozotocin: relationship of dose to metabolic response. J Clin Invest 48 2129-2139.

19. LeDoux SP, Woodley SE, Patton NJ, Wilson GL (1986) Mechanisms of nitrosourea-induced beta-cell damage. Alterations in DNA. Diabetes 35: 866872 .

20. Chattopadhyay S, Ramanathan M, Das J, Bhattacharya SK (1997) Animal models in experimental diabetes mellitus. Indian J Exp Biol 35: 1141-1145.

21. Tanko Y, Yerima M, Mahdi MA, Yaro AH, Musa KY, et al. (2008) Hypoglycemic activity of methanolic stem bark of Adansonnia digitata extract on blood glucose levels of streptozotocin-induced diabetic Wistar rats. Int J Appl Res Nat Prod $1: 32-36$

22. Ramachandran S, Rajasekaran A, Kumar KT (2011) Antidiabetic antihyperlipidemic and antioxidant potential of methanol extract of Tectona grandis flowers in streptozotocin induced diabetic rats. Asian Pac J Trop Med 4: 624-631.
23. Chandramohan G, Ignacimuthu S, Pugalendi KV (2008) A novel compound from Casearia esculenta (Roxb.) root and its effect on carbohydrate metabolism in streptozotocin-diabetic rats. Eur J Pharmacol 590: 437-443.

24. Assinewe VA, Baum BR, Gagnon D, Arnason JT (2003) Phytochemistry of wild populations of Panax quinquefolius L. (North American ginseng). J Agric Food Chem 51: 4549-4553.

25. Sasaki Y, Suzuki W, Shimada T, lizuka S, Nakamura S, et al. (2009) Dose dependent development of diabetes mellitus and non-alcoholic steatohepatitis in monosodium glutamate-induced obese mice. Life Sci 85: 490-498.

26. Matthews DR, Hosker JP, Rudenski AS, Naylor BA, Treacher DF, et al. (1985) Homeostasis model assessment: insulin resistance and beta-cell function from fasting plasma glucose and insulin concentrations in man. Diabetologia 28 412-419.

27. Fossati $P$, Prencipe $L$ (1982) Serum triglycerides determined colorimetrically with an enzyme that produces hydrogen peroxide. Clin Chem 28: 2077-2080.

28. Allain CC, Poon LS, Chan CS, Richmond W, Fu PC (1974) Enzymatic determination of total serum cholesterol. Clin Chem 20: 470-475.

29. Falholt K, Lund B, Falholt W (1973) An easy colorimetric micromethod for routine determination of free fatty acids in plasma. Clin Chim Acta 46: 105-111.

30. Friedewald WT, Levy RI, Fredrickson DS (1972) Estimation of the concentration of low-density lipoprotein cholesterol in plasma, without use of the preparative ultracentrifuge. Clin Chem 18: 499-502.

31. DobiÃ $\tilde{S}_{\text {SovÃ }}$ M, Frohlich J (2001) The plasma parameter log (TG/HDL-C) as an atherogenic index: correlation with lipoprotein particle size and esterification rate in apoB-lipoprotein-depleted plasma (FER(HDL)). Clin Biochem 34: 583588.

32. Niehaus WG Jr, Samuelsson B (1968) Formation of malonaldehyde from phospholipid arachidonate during microsomal lipid peroxidation. Eur J Biochem 6: 126-130.

33. Jiang ZY, Hunt JV, Wolff SP (1992) Ferrous ion oxidation in the presence of xylenol orange for detection of lipid hydroperoxide in low density lipoprotein Anal Biochem 202: 384-389.

34. ELLMAN GL (1959) Tissue sulfhydryl groups. Arch Biochem Biophys 82: 7077.

35. Rotruck JT, Pope AL, Ganther HE, Swanson AB, Hafeman DG, et al. (1973) Selenium: biochemical role as a component of glutathione peroxidase. Science 179: $588-590$.

36. Takahara S, Hamilton HB, Neel JV, Kobara TY, Ogura Y, et al. (1960) Hypocatalasemia: a new genetic carrier state. J Clin Invest 39: 610-619

37. Kakkar P, Das B, Viswanathan PN (1984) A modified spectrophotometric assay of superoxide dismutase. Indian J Biochem Biophys 21: 130-132.

38. Lowry OH, Rosebrough NJ, Farr AL, Randall RJ (1951) Protein measurement with the Folin phenol reagent. J Biol Chem 193: 265-275

39. Esterbauer H, Schaur RJ, Zollner H (1991) Chemistry and biochemistry of 4-hydroxynonenal, malonaldehyde and related aldehydes. Free Radic Biol Med 11: 81-128.

40. Suttle NF (1986) Copper deficiency in ruminants; recent developments. Vet Rec 119: 519-522.

41. Paglia DE, Valentine WN (1967) Studies on the quantitative and qualitative characterization of erythrocyte glutathione peroxidase. J Lab Clin Med 70: 158169

42. Sinha AK (1972) Colorimetric assay of catalase. Anal Biochem 47: 389-394.

43. Masiello $P$ (2006) Animal models of type 2 diabetes with reduced pancreatic beta-cell mass. Int J Biochem Cell Biol 38: 873-893.

44. Castaneda C (2002) Muscle wasting and protein metabolism. J Anim Sci 2: E98-E105.

45. Mishra SB, Verma A, Mukerjee A, Vijayakumar M (2011) Anti-hyperglycemic activity of leaves extract of Hyptis suaveolens L. Poit in streptozotocin induced diabetic rats. Asian Pac J Trop Med 4: 689-693.

46. Sarti C, Gallagher J (2006) The metabolic syndrome: prevalence, CHD risk and treatment. J Diabetes Complications 20: 121-132.

47. EL-Hazmi M, Warsy A (1999) Obesity, over weight and type II diabetes in Saud adult patients. Saudi Med J 20: 167-172. 
Citation: Hussein MA, Gobba NA (2013) CAMBA, a New Synthesized and Promising Protector against STZ-Induced Diabetic Complications in Rats. Med chem 3: 286293. doi: $10.4172 / 2161-0444.1000153$

48. Hussein MA, Hussein AA (2013) Biochemical effects of resveratrol and curcumin combination on obese diabetic rats. Mol and Clin Pharma 4: 1- 10.

49. Marks JB, Raskin P (2000) Cardiovascular risk in diabetes: a brief review. J Diabetes Complications 14: 108-115.

50. Wu KK, Huan Y (2007) Diabetic atherosclerosis mouse models. Atherosclerosis 191: 241-249.

51. Sivajothi V, Akalanka D, Balasundaram J, Balasubramanian R (2008) Antihyperglycemic antihyperlipidemic and antioxidant effect of Phyllanthus rheedii on streptozotocin induced diabetic rats. Iran J Pharm Res 1: 53-59.

52. Singh SK, Kesari AN, Gupta RK, Jaiswal D, Watal G (2007) Assessment of antidiabetic potential of Cynodon dactylon extract in streptozotocin diabetic rats. J Ethnopharmacol 114: 174-179.

53. Kochhar A, Malkit N, Rajbir S (2007) Effect of supplementation of traditional medicinal plants on serum lipid profile in non-insulin dependent diabetics. $J$ Hum Ecol 5: 135-40.
54. Abdalla HM Jr (2010) Purslane extract effects on obesity-induced diabetic rats fed a high-fat diet. Malays J Nutr 16: 419-429.

55. Ju JB, Kim JS, Choi CW, Lee HK, Oh TK, et al. (2008) Comparison between ethanolic and aqueous extracts from Chinese juniper berries for hypoglycaemic and hypolipidemic effects in alloxan-induced diabetic rats. J Ethnopharmacol 115: 110-115.

56. Hussein AA, Hussein MA, Soha AH, Anwar K (2013) Antidiabetic Activity of Vicia faba L. vicine and its O- deglycosylation product, divicine in STZ-induced diabetic rats. Phytopharmacology in press.

57. Hussein MA (2008) Antidiabetic and antioxidant activity of Jasonia montana extract in STZ-induced diabetic rats. SPJ 16: 214-221.

58. Hussein MA, Samir MO (2010) Structure antioxidant activity relationship and free radical scavenging capacity of hesperidin. IJPI's J Med Chem 1: 7-20.

59. Gocer H, Gulcin I (2011) Caffeic acid phenethyl ester (CAPE): correlation of structure and antioxidant properties. Int J Food Sci Nutr 62: 821-825. 